\title{
Assessing Small-Scale Farmers' Attitudes, Practices and Vulnerability to Pesticides Use in Market Gardening Crops in M'muockngie (South Western Cameroon)
}

\author{
Efuetlancha Ernest Nkemleke*
}

DIPES II, Higher Teacher Training College (ENS) Yaounde, University of Yaounde I; PhD student, University of Dschang, Cameroon

\author{
DOI: $\underline{10.36348 / \text { jaep.2020.v04i06.010 }}$ | Received: 06.06.2020 | Accepted: 13.06 .2020 | Published: 26.06 .2020
}

*Corresponding author: Efuetlancha Ernest Nkemleke

\section{Abstract}

Small-scale farmers' vulnerability to agropesticides depends largely on their attitudes and practices vis-à-vis these pesticides. This paper hinges on the causes of small-scale farmers' vulnerability to pesticide use on market garden crops in M'muockngie, South West Region of Cameroon. This study made use of household surveys to identify the origin of pesticide, types, frequency of use and the causes of farmers' vulnerability to pesticides health effects. Data analysis was at the same time manual and numeric. Findings revealed that, over $56 \%$ of small-scale farmers buy chemicals from local agrochemical input dealers. The poor handling of pesticide by small-scale farmers causes diseases like cough, itch, catarrh, nausea/vomiting, and eye redness as over $60 \%$ of farmers store pesticides at home which increases the risk of contamination. Chi-Square test results revealed that there was a significant difference between small-scale farmers' level of education as a cause of their vulnerability to pesticides harmful effects and some hypothesized explanatory variables $(\mathrm{p}<0.05)$. Training in pesticides use and the adoption of environmental-smart methods remain the best solution to safe farmers from this danger.

Keywords: Pesticide, market garden, small-scale farmers, attitudes and practices vulnerability, South West Region of Cameroon.

Copyright @ 2020: This is an open-access article distributed under the terms of the Creative Commons Attribution license which permits unrestricted use, distribution, and reproduction in any medium for non-commercial use (NonCommercial, or CC-BY-NC) provided the original author and sources are credited.

\section{INTRODUCTION}

Pesticides are important. They help farmers grow more food on less land by protecting crops from pests, diseases and weeds as well as raising productivity per hectare. This is why Abang et al., [1] posits that many farmers in Cameroon use pesticides to control pests, weeds and diseases. On the other hand, the negative effects of pesticides are widespread.

M'muockngie is a locality in Alou Subdivision, South West Region of Cameroon where market gardening crops are grown in great quantity. This locality has witnessed changes in its agrarian system from the early $1980 \mathrm{~s}$ till present. These mutations are seen in the abandonment of the old traditional farming system and/or organic farming to embrace modern system (chemical farming) which saw the introduction of pesticides in market gardening crops production. However, wrong use and overuse of pesticides in agricultural lead to both direct and indirect costs (human health) for farmers.
If pesticides initially appeared beneficial, their harmful effects are quickly highlighted and they are in particular toxic for man. Their impact depends on their mode of action, their persistence in time and their byproducts of degradation which are sometimes more toxic and are degraded less quickly than the initial compound [2]. Kopondo [3] posits that pesticides are progressively becoming recognized as one option to address yield losses due to pest attacks as well as addressing environmental degradations associated with the use. Pesticides are used on market garden crops which are primarily intended for consumption and thus have an important stake for local food [4]. These market garden crops are subdivided into three main groups; roots vegetables, leaf vegetables and fruit vegetables.

Over the years it has been seen that the Code, in conjunction with its supplementary technical guidelines, has been instrumental in assisting countries to put in place or strengthen pesticide management systems [5]. Most farmers in Cameroon use pesticides without full knowledge of the impact on human health 
and the environment [6]. The prevalent punitive environmental conditions of the study area have pushed small-scale farmers to indulge in unsustainable agricultural practices in their drive to counter the unpredictable pest and diseases infestations. Peasant farmers carrying out their various activities have contact with pesticides residues on treated farms on a daily basis, during application through spray drift, or in their homes where there are stored.

From the foregoing, it is noticed that smallscale farmers' perception of pesticides, their attitudes and their vulnerability are not just straight forward but rather multifaceted as these effects vary from one geographical location to another owing to different pesticides used with different active ingredients, use under different climatic conditions, different practices and/or culture amongst others. It is for this reason therefore that the thrust of this paper is to provide answers to the following questions: What are the types of pesticides used by small-scale farmers and their acquisition? What quantity of pesticide is used by small-scale farmers and the frequency of use? What are the causes of small-scale farmers' vulnerability to pesticides effects? The answers to the aforementioned questions aided in the attainment of the study objectives which were:

1. To identify the types of pesticides used and their sources of acquisition

2. To assess the quantity of pesticides used and the frequency of application
3. To identify the causes of small-scale farmers' vulnerability to pesticides infections.

\section{MATERIALS AND METHODS Spatial Framework}

This study was carried in M'muockngie - a locality in Alou Subdivision, South-West Region of Cameroon (Figure-1). It lies between Lat. 5 $5^{\circ} 37^{\prime} 9.59^{\prime \prime}$ and $5^{\circ} 40^{\prime} 6.85^{\prime \prime}$ North and Lon. $9^{\circ} 59^{\prime} 53^{\prime \prime}$ and $10^{\circ}$ 2'6.39" East. This subdivision falls within the relief region of the Western Highlands of Cameroon and is dominated mainly by savanna grasslands and a large secondary forest found to the West. The entire area is characterised by hilly outcrops. The principal economic activity undertaken by the inhabitants is agriculture practised mainly by small-scale farmers who inhabit the rural areas. It lies within the Cameroon Volcanic Line (CVL) with a fragile landscape characterised by a rolling topography found along the leeward side of the Bamboutos Mountain [7]. The dry season which stretches from mid-October to mid-March and the rainy season which stretches from late March to late October constitute the two main distinct seasons of this area. The long-term average temperature in Alou Subdivision is $23^{\circ} \mathrm{C}$ and the long-term annual average rainfall is $>2000 \mathrm{~mm}$ [8]. Agriculture predominates with smallscale farmers doing most of the farming. The dominant market garden crops grown are Irish potato, celery, eggplant, carrots, cabbages, huckleberry and onion, with potato, cabbage and carrot widespread.

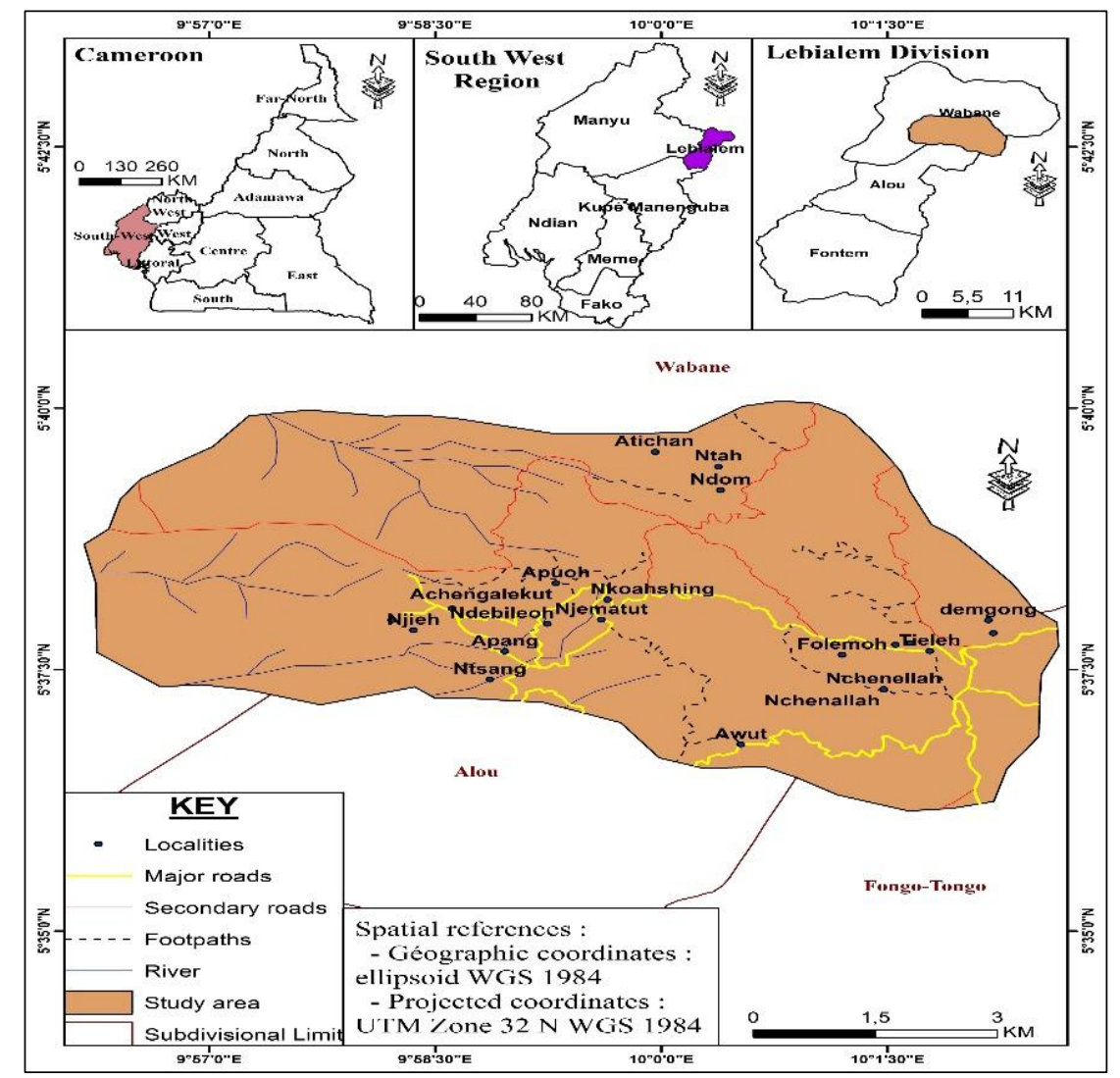

Fig-1: Location of study area

Source: Administrative map of Cameroon, drawn by the author 


\section{Sampling procedure}

A multiple phase or multi-stage sampling procedure was followed in laying out this survey. At the first phase, the study area was purposively selected owing to the high proportion of the people engaged in small-scale agriculture and the vulnerability of smallscale farmers to pesticides health effects (due principally to their limited knowledge and training in pesticides use). At the second phase, the village was grouped into four strata based on their micro agro ecological-relief characteristics (type of crop grown and altitude).

At the third phase, Stratified Random Sampling (SRS) procedure was conducted wherein small-scale farmers were stratified based on farm experience and then, were randomly selected for the survey. This was done with the help of agricultural extension officers found in this village. Mainly old and experienced farmers were sampled in order to get more reliable information pertaining to pesticides use. Following SRS, household survey of small-scale farmers was then conducted in different strata (quarters) in the surveyed area (Tieleh, Demgong, Nkoahshing and Nchenallah). The fourth stage involved Key Informant Interviews (KIIs) with village chiefs, chief of agricultural post and agricultural experts. These were conducted in order to test the veracity of the responses given by small-scale farmers during household surveys. Administering of structured and semi-structured questionnaires also preceded. A total of 101 small-scale farmer households were interviewed during the survey with a 100\% respondents' rate. Household surveys provided information on the sources of pesticides, types, frequency of application and the causes of smallscale farmers' vulnerability to pesticides used in market gardening crops. Data collection method for this study was similar to those of other related studies $[6,1,9,10]$.

\section{Data collection and analysis}

This study made use of independent explanatory variables (Table-1). Data analysis for this study was done using descriptive and inferential statistics on Microsoft Excel 2016 and SPSS 16.0 respectively. Quantity of pesticides used, causes of farmers' vulnerability to pesticides, employed both descriptive statistics (bar charts, pie charts and percentage indices) and inferential statistics (ChiSquare, Mean, and Standard Deviation). In order to determine if there was a significant difference between small-scale farmers' level of education as a cause of their vulnerability with respect to some hypothesized explanatory variables, Chi-Square $\left(x^{2}\right)$ test was used (Table 10). In this same vein, small-scale farmers' perceptions and/or attitudes towards some common farm practices were gotten through the calculation of Mean $(\bar{x})$ and Standard Deviation $(\sigma)$, (Table-9). This Mean and Standard Deviation have also been used by other authors in order to decipher farmers' adaptation strategies in farming activities [11].

Table-1: Description of variables used in the study

\begin{tabular}{|l|l|}
\hline Variable & Description \\
\hline Farm size in hectares & Continuous* \\
\hline Age & Continuous \\
\hline Age limit of handling pesticides & Continuous \\
\hline Farm experience & Continuous \\
\hline Types of pesticides & Continuous \\
\hline Sources of pesticides & Continuous \\
\hline Frequency of application & Continuous \\
\hline Quantity of pesticides use & Continuous \\
\hline Pesticides related infections & Continuous \\
\hline Spray under hot and dry weather & Dummy,* takes the value of 1 if yes and, 0 otherwise \\
\hline Spray under humid and cold weather & Dummy, takes the value of 1 if yes and, 0 otherwise \\
\hline Training in pesticides use & Dummy, takes the value of 1 if yes and, 0 otherwise \\
\hline Notice pesticides health effects & Dummy, takes the value of 1 if yes and, 0 otherwise \\
\hline Use protective devices & Dummy, takes the value of 1 if yes and, 0 otherwise \\
\hline Member of farming group & Dummy, takes the value of 1 if yes and, 0 otherwise \\
\hline Eat during application & Dummy, takes the value of 1 if yes and, 0 otherwise \\
\hline Smoke during application & Dummy, takes the value of 1 if yes and, 0 otherwise \\
\hline Drink during application & Dummy, takes the value of 1 if yes and, 0 otherwise \\
\hline Have knowledge about IPM & Dummy, takes the value of 1 if yes and, 0 otherwise \\
\hline Gender & Dummy, takes the value of 1 if male and, 0 otherwise \\
\hline Education & Dummy, takes the value of 1 if primary, 2 secondary, 3 higher \\
\hline Pesticides storage & Dummy, takes the value of 1 at home, 2 on the farm, 3 in a store \\
\hline Pesticides dosage & Dummy, takes the value of 1 if over-dose, 2 under-dose, 3 neither nor \\
\hline Dispose of empty containers & Dummy, takes the value of 1 throw on the farm, 2 wash and use, 3 burn \\
\hline
\end{tabular}

Source: Field survey, 2017

*Continuous means a discrete variable that can take on an uncountable set of values either numeric or time/date

*Dummy means a numerical variable that represent categorical data such as gender, race etc. 


\section{RESULTS}

Market gardening farming: An activity that dominates highland areas

Zones of intensive market gardening production in the study area are mostly concentrated on highlands and/or hill slopes (Figure-2). The Agrarian system of this area has a high altitudinal organisation from valleys to hilltops (owing principally to the rugged topography of this village). The parcels are made of mixed cropping of several market gardening crops like carrot, huckleberry and leeks (cf. Insert 1).

\section{Insert 1}

I cultivate different crops on the same piece of land (mixed cropping) to reduce crop failure and in situation where the land is not enough to plant single crop. This mixed cropping system is also a method to prevent diseases and pest attacks on the crops and minimise loses.

Peasant farmer, at Tieleh, M'muockngie

The intensive cultivation of these crops on hill slopes and highlands is assisted by a drainage system put up by local peasants i.e. irrigation as well as the use of organic fertilizers and chemical pesticides.

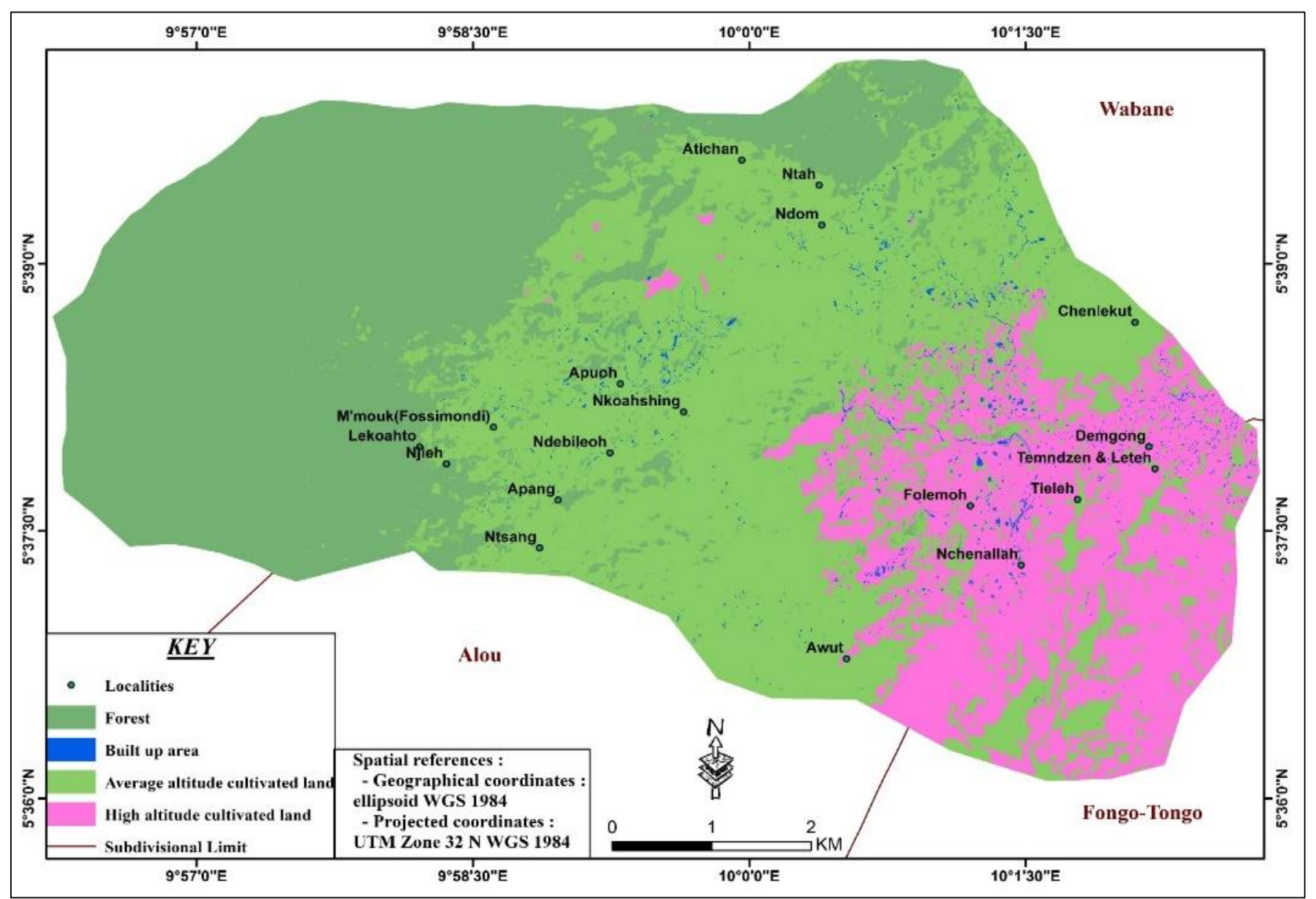

Fig-1: Zones of market gardening crop production

Source: Administrative map of Cameroon, drawn by the author

Use of pesticide: A system of plant protection involving pesticides with different active ingredients

Findings regarding the type of pesticides used in the study area revealed that, fungicides, insecticides and herbicides are the major pesticides used. These pesticides are grouped by their trade names, active ingredients and World Health Organization (WHO) chemical hazards category with class II (moderately hazardous) and class III (unlikely to cause hazards) (Table-2). From empirical findings, some farmers used a combination of different pesticides to treat a single crop. Peasant farmers mixed fungicides and insecticides to spray tomatoes. Some mixed fertilizers and fungicides to treat Irish potatoes (cf. Insert 2). It is worth nothing here that using a particular chemical on a type of crop not intended to be used on, is harmful both to the crop and human health. 
Efuetlancha Ernest Nkemleke; J Adv Educ Philos, June, 2020; 4(6): 295-305

Table-2: Type of pesticides use in M'muockngie

\begin{tabular}{|c|c|c|c|c|c|c|}
\hline Pesticides & $\begin{array}{l}\text { Product } \\
\text { Name }\end{array}$ & Active ingredients & $\begin{array}{l}\text { Toxic } \\
\text { class }\end{array}$ & $\begin{array}{l}\text { Prescribed } \\
\text { dosage }\end{array}$ & Restricted areas & Specialisation \\
\hline \multirow{11}{*}{ FUNGICIDE } & Guardien & Mancozèbe & III & $2 \mathrm{~kg} \mathrm{p.c./ha}$ & $\begin{array}{l}\text { Wear protective } \\
\text { clothing }\end{array}$ & Market gardening \\
\hline & $\begin{array}{l}\text { Mancozeb } \\
\text { Blus }\end{array}$ & Mancozèbe & & & & Market gardening \\
\hline & Kozeb & & III & $2 \mathrm{~kg} \mathrm{p.c/ha}$ & $\begin{array}{l}\text { Use far from homes } \\
\text { and water sources }\end{array}$ & Tomato \\
\hline & Mancosam & Metalaxyl & III & $\begin{array}{l}50 \mathrm{~g} \mathrm{p} . \mathrm{c} / 15 \mathrm{~L} \\
\text { sprayer }\end{array}$ & & Tomato \\
\hline & Egrowcare 80 & $\begin{array}{l}\text { Dimethomorphe+600 } \\
\text { and copper Oxide }\end{array}$ & & $1,2 \mathrm{~kg} \mathrm{p.c/h}$ & $\begin{array}{l}\text { Wear protective } \\
\text { clothing; use far } \\
\text { from water sources }\end{array}$ & Fruit bearing \\
\hline & Banco plus & $\begin{array}{l}\text { Chlorothalonil } 550 \mathrm{~g} / \mathrm{l} \\
\text { +Carbendazime } 100 \\
\mathrm{~g} / \mathrm{l}\end{array}$ & III & 3L p.c./ha & & \\
\hline & Coga $80 \mathrm{WP}$ & Mancozèbe & III & $\begin{array}{l}\text { 2kg p.c./ha } \\
\text { (1600g m.a./ha) }\end{array}$ & $\begin{array}{l}\text { Wear protective } \\
\text { clothing }\end{array}$ & Tomato \\
\hline & Metazeb & Metalaxyl mancozeb & & $1,2 \mathrm{~kg}$ p.c./ha & Wear eye glasses & Tomato \\
\hline & Plantineb & Maneb & III & $2 \mathrm{~kg}$ p.c./ha & & Market gardening \\
\hline & Baobab & Mancozèbe $800 \mathrm{~g} / \mathrm{kg}$ & III & $\begin{array}{l}85 \mathrm{~g} \text { p.c. } / 15 \mathrm{~L} \\
\text { sprayer }\end{array}$ & & Tomato \\
\hline & Penncozeb 80 & Mancozèbe $80 \%$ & III & $\begin{array}{l}1,7-2,5 \mathrm{~kg} \\
\text { p.c/ha }\end{array}$ & & Market gardening \\
\hline \multirow{6}{*}{ INSECTICIDE } & Quiclear & Glyphosate & & & & Fruit bearing \\
\hline & $\begin{array}{l}\text { Capt forte } 180 \\
\text { WP }\end{array}$ & $\begin{array}{l}\text { Lamdacyphalothrine + } \\
\text { acetamipride }\end{array}$ & II & $\begin{array}{l}125 \mathrm{~g} \text { p.c./ha } \\
(6,25 \text { g p.c./ } 15 \mathrm{~L} \\
\text { sprayer })\end{array}$ & $\begin{array}{l}\text { Wear protective } \\
\text { clothing }\end{array}$ & Tomato \\
\hline & Parastar $40 \mathrm{EC}$ & $\begin{array}{l}\text { Imidaclopride } 20 \mathrm{~g} / \mathrm{l}+ \\
\text { Lambdacyhalothrine } \\
20 \mathrm{~g} / \mathrm{l} \mathrm{EC}\end{array}$ & & & & Market gardening \\
\hline & Cigogne & $\begin{array}{l}\text { Cypermethrine } 360 \mathrm{~g} / \mathrm{l} ; \\
\text { Ec }\end{array}$ & II & 3L p.c./ha & $\begin{array}{l}\text { Wear protective } \\
\text { clothing, respect the } \\
\text { time interval }\end{array}$ & Market gardening \\
\hline & K-Optimal & $\begin{array}{l}\text { Lambdacyhalothrine } \\
15 \mathrm{~g} / 1+\text { Acetamipride } \\
20 \mathrm{~g} / \mathrm{l} \mathrm{EC}\end{array}$ & II & $\begin{array}{l}\text { 1L p.c./ha ( } 40 \\
\text { ml p.c / } 15 \mathrm{~L} \\
\text { sprayer) }\end{array}$ & $\begin{array}{l}\text { Wear protective } \\
\text { clothing }\end{array}$ & Tomato \\
\hline & Pyriforce & $\begin{array}{l}\text { Chlorphriphos-ethyl } \\
600 \mathrm{~g} / 1 ; \text { EC }\end{array}$ & & & & Market gardening \\
\hline \multirow{5}{*}{ HERBICIDES } & $\begin{array}{l}\text { Super } \\
\text { Machette } \\
\end{array}$ & Glyphosate & & 1,25 kg p.c. $/ \mathrm{ha}$ & $\begin{array}{l}\text { Far from water } \\
\text { sources }\end{array}$ & Market gardening \\
\hline & $\begin{array}{ll}\text { Tromissil } & 50 \\
\text { WP } & \\
\end{array}$ & Linuron & & & & Carrot \\
\hline & $\begin{array}{l}\text { Glyphader } 360 \\
\text { SL }\end{array}$ & Glyphosate & III & $\begin{array}{l}\text { 1,5-8L p.c./ha } \\
(540-2880 \mathrm{~g} \\
\text { m.a./ha) }\end{array}$ & $\begin{array}{l}\text { Wear protective } \\
\text { clothing }\end{array}$ & $\begin{array}{l}\text { Adventitious of } \\
\text { plant }\end{array}$ \\
\hline & $\begin{array}{l}\text { Gramaxone } \\
\text { Supper }\end{array}$ & Paraquat $200 \mathrm{~g} / \mathrm{l}$ & & & & Diverse crops \\
\hline & Imida & Imidaclopride & II & 1L p.c./ha & & Diverse crops \\
\hline
\end{tabular}

Source: Field survey, 2017

\section{Insert 2}

I mix two or more different type of pesticides in the same knapsack sprayer to treat our crops because I have noticed that when I over-dosed the chemicals the rate of diseases attack reduces as the combination rapidly eliminates some diseases that are resistant.

Peasant Farmer, at Nchenallah, M'muockngie

\section{Sources of pesticide: buying at local market shops is most common}

Small-scale farmers get pesticides from different sources where some of these sources are not reliable. Findings emanating from household surveys revealed that small-scale farmers buy pesticides from different sources (Table-3). The commonest sources where small-scale farmers obtain pesticides are from local shops in the village market (over 56\%), farming groups or associations (over 19\%), and retail shops in town (over 15\%) and from agriculture extension service or technician (over 7\%). For farmers who buy in town, Dschang serves as the main centre for acquisition of farm inputs and sale of some of the farm produce. 
Table-3: Acquisition of pesticides

\begin{tabular}{|l|l|l|}
\hline Source & $\begin{array}{l}\text { Frequency of respondents } \\
\text { n=101 }\end{array}$ & $\%$ \\
\hline From local shops (local agrochemical input dealers) & 57 & 56.4 \\
From farming groups & 20 & 19.8 \\
From town (Dschang) & 16 & 15.8 \\
From agriculture technician in the village & 8 & 7.9 \\
\hline
\end{tabular}

Source: Own field survey, 2017

Pesticides use in market gardening crops: quantity measured in litres/sachets per hectare

The intensification of market gardening crops in the study area reflects the quantity of pesticides used. Amongst the sampled quarters, Nkoahshing is the area where pesticides are used in greater quantity with 4.4 litres/sachets of pesticides used per hectare each day on an average (Table-4). Findings revealed that, 35\% of farmers use between 76-90 litres/sachets of pesticides per hectare per agricultural season in areas like
Nchenallah and Demgong. Also, 25\% of farmers used more than 90 litres/sachets of pesticides per season. Localities that have the lowest quantities of pesticides use on a whole are Nchenallah and Demgong (with averages of 2.8 litres/sachets per ha. /day). This can be due to the fact that, there are fewer peasant farmers in these two localities as compared to other localities like Tieleh and Nkoahshing where a bulk of the village population inhabit and practice agriculture.

Table-4: Quantity of pesticides used per hectare

\begin{tabular}{|c|c|c|c|c|c|c|c|c|}
\hline \multirow{3}{*}{$\begin{array}{l}\text { Pesticides used } \\
\text { (Litres or sachets/ } \\
\text { ha./season) }\end{array}$} & \multicolumn{8}{|l|}{ Quarter } \\
\hline & \multicolumn{2}{|l|}{ Tieleh } & \multicolumn{2}{|c|}{ Demgong } & \multicolumn{2}{|c|}{ Nkoahshing } & \multicolumn{2}{|c|}{ Nchenallah } \\
\hline & $\begin{array}{l}\% \text { of } \\
\text { farmers }\end{array}$ & $\begin{array}{l}\text { Cumulative } \\
\%\end{array}$ & $\begin{array}{l}\% \text { of } \\
\text { farmers }\end{array}$ & $\begin{array}{l}\text { Cumulative } \\
\%\end{array}$ & $\begin{array}{l}\% \text { of } \\
\text { farmers }\end{array}$ & $\begin{array}{l}\text { Cumulative } \\
\%\end{array}$ & $\begin{array}{l}\% \text { of } \\
\text { farmers }\end{array}$ & $\begin{array}{l}\text { Cumulative } \\
\%\end{array}$ \\
\hline 1-15 litres & 3.3 & 3.3 & 5 & 5 & 9.7 & 9.7 & 5 & 5 \\
\hline 16-30 litres & 3.3 & 6.6 & 5 & 10 & 9.7 & 19.4 & 5 & 10 \\
\hline $31-45$ litres & 10 & 16.6 & 5 & 15 & 9.7 & 29.1 & 5 & 15 \\
\hline 46-60 litres & 16.7 & 33.3 & 10 & 25 & 12.9 & 42 & 15 & 30 \\
\hline 61-75 litres & 20 & 53.3 & 25 & 50 & 19.3 & 61.3 & 10 & 40 \\
\hline 76-90 litres & 30 & 83.3 & 35 & 85 & 25.8 & 87.1 & 35 & 75 \\
\hline 91 litres > & 16.7 & 100 & 15 & 100 & 12.9 & 100 & 25 & 100 \\
\hline Average & \multicolumn{2}{|l|}{4.3} & \multicolumn{2}{|l|}{2.8} & \multicolumn{2}{|l|}{4.4} & \multicolumn{2}{|l|}{2.8} \\
\hline
\end{tabular}

Pesticides spraying calendar: a weekly routine activity in intensifying market gardening crops productivity

Pesticides use has become a weekly routine activity within households and/or small-scale farmers in this locality. Small-scale farmers apply pesticides on weekly basis. Findings on the weekly schedule of small-scale farmers' pesticides spraying calendars revealed that, the highest number of sprays per week is carried out in Demgong. Here, over $15 \%$ of farmers spray approximately 13 times and above in a week as compared to over $6 \%, 9 \%$ and $10 \%$ in Tieleh, Nkoahshing and Nchenallah respectively, with $35 \%$ spraying between 10-12 times per week in the same locality (Table-5). Whereas in other places like Nchenallah and Nkoahshing many farmers spray between 10-12 times per week than in Demgong. The disparities between small-scale farmers' spraying calendars are due principally to differences in perception of pests and diseases attacks on crops. The purchasing power and/or household income of smallscale farmers in these localities is no exception. Some are unable to afford for the chemical pesticides which permit them spray on a daily basis like others. Therefore, pesticides spraying calendar differs between peasants so too their methods of intensifying market gardening crop production.

Table-5: Pesticides spraying calendar

\begin{tabular}{|c|c|c|c|c|c|c|c|c|}
\hline \multirow{3}{*}{$\begin{array}{lr}\text { No. } & \text { of } \\
\text { applications } \\
\text { month }\end{array}$} & \multicolumn{8}{|l|}{ Ouarter } \\
\hline & \multicolumn{2}{|l|}{ Tieleh } & \multicolumn{2}{|l|}{ Demgong } & \multicolumn{2}{|c|}{ Nkoahshing } & \multicolumn{2}{|l|}{ Nchenallah } \\
\hline & $\begin{array}{l}\% \text { of } \\
\text { farmers }\end{array}$ & $\begin{array}{l}\text { Cumulative } \\
\%\end{array}$ & $\begin{array}{l}\% \text { of } \\
\text { farmers }\end{array}$ & $\begin{array}{l}\text { Cumulative } \\
\%\end{array}$ & $\begin{array}{l}\text { \% of } \\
\text { farmers }\end{array}$ & $\begin{array}{l}\text { Cumulative } \\
\%\end{array}$ & $\begin{array}{l}\% \text { of } \\
\text { farmers }\end{array}$ & $\begin{array}{l}\text { Cumulative } \\
\%\end{array}$ \\
\hline $1-3$ times & 13.3 & 13.3 & 10 & 10 & 9.7 & 9.7 & 10 & 10 \\
\hline $4-6$ times & 26.7 & 40 & 20 & 30 & 19.3 & 29 & 10 & 20 \\
\hline $7-9$ times & 33.3 & 73.3 & 20 & 50 & 25.8 & 54.8 & 30 & 50 \\
\hline 10-12 times & 20 & 93.3 & 35 & 85 & 35.5 & 90.3 & 40 & 90 \\
\hline 13 times $>$ & 6.7 & 100 & 15 & 100 & 9.7 & 100 & 10 & 100 \\
\hline Average & 6 & & 4 & & 6.2 & & 4 & \\
\hline
\end{tabular}




\section{Pesticides: Useful but dangerous}

Pesticides are important. They help farmers grow more food on less land by protecting crops from pests, diseases and weeds as well as raising productivity per hectare. Hazard identification or safety evaluation studies also revealed the inherent toxicological properties of chemicals on small-scale farmers. Pesticide poisonings and illnesses are clearly the highest price paid by all pesticide users. The symptoms related to pesticides poisoning differed from one locality to another due to different pesticides application rates, farmers' perceptions, attitudes and precautions. Specific health symptoms that farmers only witnessed on them when they started spraying and after hours of pesticides spraying were also observed.

In Tieleh, cough was the main toxicology symptoms farmers witnessed (over $96 \%$ for male farmers) while female farmers witnessed over $86 \%$ (Table-6), meanwhile, in Demgong, $85 \%$ and $90 \%$ of male and female farmers have cough after pesticides treatment respectively. The most dominant in the study area were mostly cough, general body weakness, catarrh, itch, headache, eye redness and sneezing with Tieleh and Nkoahshing registering the highest number of the symptoms (Table-6).

Table-6: Pesticides related health effects

\begin{tabular}{|c|c|c|c|c|c|c|c|c|}
\hline \multirow{3}{*}{$\begin{array}{l}\text { Symptoms } \\
\text { (ranked in order } \\
\text { of intensity) }\end{array}$} & \multicolumn{8}{|c|}{ Quarter } \\
\hline & \multicolumn{2}{|c|}{ Tieleh } & \multicolumn{2}{|c|}{ Demgong } & \multicolumn{2}{|c|}{ Nkoahshing } & \multicolumn{2}{|c|}{ Nchenallah } \\
\hline & $\begin{array}{l}\text { Male } \\
(\%)\end{array}$ & $\begin{array}{l}\text { Female } \\
(\%)\end{array}$ & $\begin{array}{l}\text { Male } \\
(\%)\end{array}$ & $\begin{array}{l}\text { Female } \\
(\%)\end{array}$ & $\begin{array}{l}\text { Male } \\
(\%)\end{array}$ & $\begin{array}{l}\text { Female } \\
(\%)\end{array}$ & $\begin{array}{l}\text { Male } \\
(\%)\end{array}$ & $\begin{array}{l}\text { Female } \\
(\%)\end{array}$ \\
\hline 1. Cough & 96.7 & 86.7 & 85 & 90 & 45.2 & 80.6 & 75 & 90 \\
\hline 2. Itch & 53.3 & 73.3 & 90 & 95 & 45.2 & 58.1 & 65 & 90 \\
\hline 3. Cold & 33.3 & 90 & 40 & 80 & 48.1 & 96.8 & 55 & 80 \\
\hline 4. Nausea/Vomiting & 33.3 & 83.3 & 60 & 45 & 58.1 & 90.3 & 55 & 90 \\
\hline 5. Eye redness & 66.7 & 93.3 & 80 & 60 & 29 & 41.9 & 55 & 85 \\
\hline 6. Headache & 76.7 & 83.3 & 60 & 50 & 35.5 & 80 & 25.8 & 75 \\
\hline 7. Excessive heat & 86.7 & 93.3 & 45 & 55 & 45.2 & 64.5 & 45 & 50 \\
\hline 8. Toxicity & 83.3 & 50 & 40 & 55 & 38.7 & 61.3 & 70 & 85 \\
\hline 9. Fever & 60 & 80 & 55 & 85 & 29 & 45.2 & 50 & 70 \\
\hline 10. Body weakness & 33.3 & 73.3 & 30 & 50 & 54.8 & 83.9 & 38.7 & 75 \\
\hline 11. Sneezing & 80 & 60 & 55 & 25 & 41.9 & 58.1 & 25.8 & 38.7 \\
\hline 12. Stomach ache & 30 & 36.7 & 25 & 40 & 16.1 & 29 & 20 & 30 \\
\hline
\end{tabular}

Source: Own field data, 2017.

*Farmers experience a combination of more than one symptom.

\section{Pesticides dosage: quantity measured with the desire to achieve high yields}

Each chemical is manufactured for a particular purpose and a dosage that assures it proper functioning in killing pest and diseases. However, small-scale farmers use abnormal dosage (over dose and under dose).

Data sourced from farmers revealed that, some pesticides users over dose and under dose pesticides than the normal dosage stated on pesticides containers/packaging. Over $79 \%$ of farmers over-dose pesticides and this account for the numerous health problems in this area. Conversely, over $4 \%$ under-dose pesticides while $15.84 \%$ neither over-doe nor underdose (Figure-3). As a result, poor handling of pesticide is more delicate as most small-scale farmers mostly the rural population are less educated, which is one of the main reasons why the population is vulnerability to pesticides effects. Most of them depend on the experience of other farmers for advice.

Similarly, when farmers notice that pests and diseases have increased, they increase the dosage in order to prevent the wrath of pests and diseases on the crops (cf. Insert 2). It was also found that farmers have little or no contact with agricultural technicians instead; they seek advice from their counterparts.

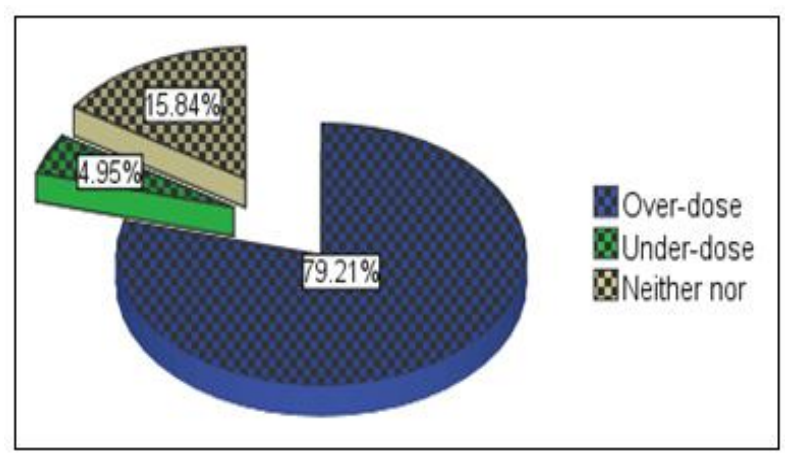

Fig-3: Pesticides dosage

Pesticides storage: stored at home, but the most delicate place

Small-scale farmers have commodity stores where they keep pesticides (over 33\%), but over $60 \%$ store pesticides at home while just over $5 \%$ of farmers keep them away from home (Table-7). Farmers without commodity stores keep pesticides at home. Storing pesticides at home increases small-scale farmers' vulnerability as they have direct contact with the chemicals on a daily basis. Some farmers buy only the quantity needed for immediate use. 
Table-7: Pesticides storage

\begin{tabular}{|l|l|l|}
\hline Storage & Frequency of respondents & \% \\
\hline At home & 61 & 60.4 \\
Commodity store & 34 & 33.7 \\
At the farm & 6 & 5.9 \\
\hline
\end{tabular}

Source: Own field survey, 2017

\section{Dispose of empty containers: throwing on the farm is the dominant method}

Data sourced on the methods of dispose of empty pesticides containers/packaging revealed that, over $42 \%$ of farmers throw empty containers on farms while just over $15 \%$ burn the containers after use. Over $41 \%$ of them wash the containers and use as storage containers for foodstuffs at home (Table-8).

Table-8: Dispose of pesticides empty containers

\begin{tabular}{|l|l|l|}
\hline $\begin{array}{l}\text { Dispose of empty } \\
\text { packaging }\end{array}$ & $\begin{array}{l}\text { Frequency of } \\
\text { respondents }\end{array}$ & $\%$ \\
\hline Throw at the farm & 43 & 42.6 \\
Wash and use at home & 42 & 41.6 \\
Burn & 16 & 15.8 \\
\hline
\end{tabular}

Source: Own field survey, 2017
Small-scale farmers' attitudes in pesticides using Mean and Standard Deviation

Farmers' opinions on some common farm practices when using pesticides were analysed with mean and standard deviation to express how farmers' attitudes in the use of pesticides differ from one farm practice to another. In this locality, small-scale farmers have not undergone training in pesticides use $(\bar{x}=$ 1.89), farmers spray pesticides under hot/dry and windy weather condition which is not advisable $(\bar{x}=1.24)$, farmers do not spray under cold/wet and humid condition which is instead the most suitable ( $\bar{x}=$ 1.89 ), farmers notice pesticides health effects on themselves $(\bar{x}=1.09)$, small-scale farmers do not use protective devices during pesticides application ( $\bar{x}=1.79$ ), farmers do not eat during pesticides application $(\bar{x}=1.80)$, farmers drink during pesticides application $(\bar{x}=1.31)$, smoke during pesticides application $(\bar{x}=1.26)$, they equally do not have knowledge of other methods of plant protection i.e. Integrated Pest Management-IPM $(\bar{x}=1.81)$ and ultimately do not keep records of pesticides active ingredients $(\bar{x}=1.90)$, (Table-9).

Table-9: Small-scale farmers' attitudes in pesticides

\begin{tabular}{|l|l|l|l|l|l|l|}
\hline Farm practices & $\mathbf{N}^{\mathbf{0}}$ & $\mathbf{M i n}$ & $\mathbf{M a x}$ & $\mathbf{M e a n}$ & Std. Deviation & Remark \\
\hline 1. Receive training in pesticides use & 101 & 1 & 2 & 1.89 & .313 & Rejected \\
\hline 2. Spray pesticides under hot/dry and windy weather condition & 101 & 1 & 2 & 1.24 & .428 & Accepted \\
\hline 3. Spray pesticides under cold/wet and humid weather condition & 101 & 1 & 2 & 1.89 & .313 & Rejected \\
\hline 4. Notice pesticides health effects & 101 & 1 & 2 & 1.09 & .286 & Accepted \\
\hline 5. Use protective devices & 101 & 1 & 2 & 1.79 & .408 & Rejected \\
\hline 6. Eat during application & 101 & 1 & 2 & 1.80 & .400 & Rejected \\
\hline 7. Drink during application & 101 & 1 & 2 & 1.31 & .464 & Accepted \\
\hline 8. Smoke during application & 101 & 1 & 2 & 1.26 & .439 & Accepted \\
\hline 9. Have knowledge about IPM & 101 & 1 & 2 & 1.81 & .393 & Rejected \\
\hline 10. Keep record of pesticides active ingredients & 101 & 1 & 2 & 1.90 & .300 & Rejected \\
\hline
\end{tabular}

Source: Calculations based on field data, 2017

*Accepted $(\bar{x}<1.5)$, Rejected $(\bar{x}>1.5)$

\section{Impact of weighted variables}

In order to test whether there was a significant difference between small-scale farmers' vulnerability to pesticides and several hypothesized explanatory variables, the Chi-Square test was used. The Chi-Square test results revealed that there was a significant difference between small-scale farmers' level of education as a main cause of vulnerability with respect to receiving training in pesticides use, spraying pesticides under hot/dry and windy weather condition, perception of pesticides health effects, use protective devices, drinking during application, smoking during application, have knowledge about Integrated Pest Management (IPM), keeping record of pesticides active ingredients, member of any agricultural group and gender $(p<0.05)$ with Chi-square values of 5.272 , 13.722, 21.095, 22.062, 22.382, 21.545, 12.854, 14.980, 15.587 and 17.520 respectively (Table 10). This implies that as small-scale farmers spray pesticides under hot/dry and windy weather condition, do not use protective devices, smoke during application, have little knowledge about IPM, do not keep record of pesticides active ingredients, do not belong to a farming group, the higher the likelihood to be affected by pesticides poisoning. With the p-levels being statistically significant $(p<0.05)$, it implies that there was a $95 \%$ probability that these events did not happen by chance. 
Efuetlancha Ernest Nkemleke; J Adv Educ Philos, June, 2020; 4(6): 295-305

Table-10: Summary of the Chi-Square test result

\begin{tabular}{|c|c|c|c|c|c|}
\hline Variable & Description & $\begin{array}{l}\text { Frequency } \\
\text { (n) }\end{array}$ & $\%$ & Chi-Square & p-level \\
\hline \multirow[t]{2}{*}{ Receive training in pesticides use } & Yes & 21 & 20.8 & \multirow[b]{2}{*}{5.272} & \multirow[b]{2}{*}{$0.022 *$} \\
\hline & No & 80 & 79.2 & & \\
\hline \multirow[t]{2}{*}{ Spray pesticides under hot/dry and windy weather condition } & Yes & 70 & 69.3 & \multirow[b]{2}{*}{13.722} & \multirow[b]{2}{*}{$0.017 *$} \\
\hline & No & 31 & 30.7 & & \\
\hline \multirow[t]{2}{*}{ Spray pesticides under cold/wet and humid weather condition } & Yes & 13 & 12.9 & \multirow[b]{2}{*}{3.993} & \multirow[b]{2}{*}{$0.550^{\mathrm{ns}}$} \\
\hline & No & 88 & 87.1 & & \\
\hline \multirow[t]{2}{*}{ Notice pesticides health effects } & Yes & 65 & 64.4 & \multirow[b]{2}{*}{21.095} & \multirow[b]{2}{*}{$0.001 *$} \\
\hline & No & 36 & 35.6 & & \\
\hline \multirow[t]{2}{*}{ Use individual protective devices } & Yes & 21 & 20.8 & \multirow[b]{2}{*}{22.062} & \multirow[b]{2}{*}{$0.001 *$} \\
\hline & No & 80 & 79.2 & & \\
\hline \multirow[t]{2}{*}{ Eat during application } & Yes & 7 & 6.9 & \multirow[b]{2}{*}{7.645} & \multirow[b]{2}{*}{$0.177^{\mathrm{ns}}$} \\
\hline & No & 94 & 93.1 & & \\
\hline \multirow[t]{2}{*}{ Drink during application } & Yes & 59 & 58.4 & \multirow[b]{2}{*}{22.382} & \multirow[b]{2}{*}{$0.000 *$} \\
\hline & $\mathrm{No}$ & 42 & 41.6 & & \\
\hline \multirow[t]{2}{*}{ Smoke during application } & Yes & 62 & 61.4 & \multirow[b]{2}{*}{21.545} & \multirow[b]{2}{*}{$0.001 *$} \\
\hline & No & 39 & 38.6 & & \\
\hline \multirow[t]{2}{*}{ Have knowledge about IPM } & Yes & 32 & 31.7 & \multirow[b]{2}{*}{12.854} & \multirow[b]{2}{*}{$0.025^{*}$} \\
\hline & No & 69 & 68.3 & & \\
\hline \multirow[t]{2}{*}{ Keep record of pesticides active ingredients } & Yes & 21 & 20.8 & \multirow[b]{2}{*}{14.980} & \multirow[b]{2}{*}{$0.010^{*}$} \\
\hline & No & 80 & 79.2 & & \\
\hline \multirow[t]{2}{*}{ Gender } & Male & 65 & 64.4 & \multirow[b]{2}{*}{17.520} & \multirow[b]{2}{*}{$0.004 *$} \\
\hline & Female & 36 & 35.6 & & \\
\hline \multirow[t]{2}{*}{ Member of agricultural group } & Yes & 39 & 38.6 & & \\
\hline & No & 62 & 61.4 & 15.587 & $0.008 * * *$ \\
\hline
\end{tabular}

Source: Own field data (Sept. 2017)

*Significant at $5 \%(\mathrm{df}=5 ; \mathrm{p}<0.05) ; \mathrm{ns}=$ not significant

However, the Chi-Square test did not show any statistically significant difference $(\mathrm{p}>0.05)$, between small-scale farmers' level of education as a cause of their vulnerability with regards to spraying pesticides under cold/wet and humid weather condition and eating during application. This shows that these variables have no significant influence on small-scale farmers' vulnerability to pesticides.

\section{DISCUSSION}

A keen analysis of the findings of this study show that, small-scale farmers acquire pesticides from diverse sources viz. local agrochemical input dealers, farming groups and/or cooperatives groups, in agrochemical shops in the town of Dschang and as subventions from agricultural technicians with majority of farmers acquiring chemicals from local shops in the village. This finding authenticates the research findings of Abang et al., [1] that opined that peasant farmers mostly buy chemicals from local agro-input dealers and are unable to distinguish between different pest and disease pathogens and control measures such as insecticides and fungicides and rely on information and advice provided by local agro-input dealers for decision making which are sometime misleading.

Small-scale farmers are increasingly involved in the use of pesticides in boosting crop productivity. They spray pesticides on daily and weekly schedules. Data sourced from the targets show small-scale farmers cultivate mostly in the rainy season (because of the prolonged rainy season and a short dry season) and as such, most farmers spray pesticides about 2 to 3 times per week. This result refutes the idea of Tandi et al., [12] that opined that farmers (less than 15\%) cultivate in the rainy season which obliges them to spray in the rainy season. Spraying in the rainy season obliges small-scale farmers to use a large quantity of pesticides given that pests and diseases infestation augment in the rainy season thereby increasing their likelihood of being harmed. It is worth stressing that the frequency of application depends on the rate of prevalence of pest and diseases. Farmers therefore choose to augment their spraying interval due to pests and diseases attack. This finding authenticates the findings of Abang et al., [1]. These findings therefore lend credibility to the present study, proving that, weekly pesticide spraying is the most common due to the rapid spread of pests and diseases.

Pesticides seem to be the best method of plant protection and increasing agricultural productivity. The negative externalities that come as a result of pesticides use are worth documenting. Finding revealed that small-scale farmers who use pesticides on a daily basis are vulnerable to the negative effects of pesticides. These effects are multifaceted in the form of symptoms like cough, toxicity, headache, itches, eye redness and vomiting among others. This finding sharply corroborates with the findings of Ajayi [13] where he 
demonstrates that the main symptoms reported by pesticides users are headache, catarrh, cough, skin rash and sneezing. There is no marked different between the two findings and therefore, it lends credibility to the present findings. Other studies $[14,15]$ show that smallscale farmers in their endeavours to fight against the ravaging pests and diseases in crops also loss a great labour force which is a significant factor in agricultural production especially in the developing countries. These pesticides lower aggregate potential output through their negative impacts on the health of household members and farm workers. Data sourced from small-scale farmers in the study area show that labour is reduced when farmers are affected by pesticides. Some farmers ignore these symptoms because of some lukewarm [ ${ }^{1}$ ] attitudes. This corroborates the findings of Tandi et al., [12] where farmers avoid medical care on the assumption that signs and symptoms of pesticides poisoning are normal phenomena and need no medical attention as they disappeared themselves. This lukewarm attitude further broadens the risk of long term effects of pesticides poisoning.

This study has proven that small-scale farmers re-use pesticides empty containers at home while some dump the packaging into water courses. They also store pesticides at home which increase their vulnerability. This authenticates the findings of Kenko et al., [16] conducted in Buea, South West Cameroon; where empty sachets of pesticides are mainly thrown in the water or in the bush. Similarly, large plastic containers are mostly washed and used for other purposes such as storage of grain crops, kerosene and palm oil by farmers in Cameroon [17, 18].

This survey also revealed that small-scale farmers do not make use of individual protective clothing while using pesticides. This corroborates other findings $[18,19,16]$ that show that farmers spray without body covering. The current research equally found that small-scale farmers smoke and drink while spraying pesticides and some farmers used pesticides intended for a specific crop on several crops. Some mix fertilizer with pesticide to spray market gardening crops. This finding is in line with the findings of Amuoh [19] that show that farmers smoke, eat and drink during spraying and use pesticides meant for cocoa or cotton on fruits and vegetables.

Farmers are increasingly aware of the negative impacts of pesticides on their health. They sometimes over-dose pesticides to acquire a greater output that can

\footnotetext{
${ }^{1}$ Small-scale farmers believe that their grandparents used pesticides without individual protective clothing and were never killed by pesticides intoxication. Therefore, symptoms of pesticides health effects according to small-scale farmers are normal symptoms and disappear themselves.
}

sustain their household. Over-dose is more common among farmers who lack the basic knowledge on the effects of over-dose which exposes them to the negative effects of pesticides. This lack of knowledge is justified by the fact that agricultural technicians and/or experts do have make routine visits to sensitize farmers on the use of these chemicals. Small-scale farmers rather seek advice from neighbours and farmer counterpart. This corroborates the results of Elizabeth \& Zira [20]. Findings also revealed that, small-scale farmers are more exposed to pesticides poisoning during product mixing due to the poor methods which expose them to the chemicals. This authenticates the results of Tandi et al., [12] that show that methods used by most farmers expose them to acute effects of pesticide.

\section{CONCLUSION}

This study revealed that small-scale farmers in the sampled area witness pesticides acute effects. Farmers generally witness a combination of effects. The most recurrent health effects identified are cough, itch, catarrh, nausea/vomiting and eye redness while the least recurrent are stomach ache, sneezing, body weakness and fever. Pertaining to the causes of small-scale farmers' vulnerability to pesticides, the most identified causes are over-dose of pesticides (over 79\%), no protective device used (over 79\%), no training in pesticides use (over 79\%), spray in windy weather conditions (over 69\%), smoke during application (over $61 \%$ ), store pesticides at home (over 60\%), drink during application (over 58\%), while the least causes of vulnerability are eating during application (6.9\%) and spraying under cold weather (12.9\%). Chi-Square analysis revealed a statistically significant difference between small-scale farmers' level of education as a main cause of their vulnerability with respect to some hypothesized explanatory variables $(p<0.05)$. Therefore, small-scale farmers will avoid pesticide acute effects if younger farmers receive advice and training from their older and trained counterparts.

\section{REFERENCES}

1. Abang, A. F., Kouame, C. M., Abang, M., Hannah, R., \& Fotso, A. K. (2013). Vegetable growers perception of pesticide use practices, cost, and health effects in the tropical region of Cameroon. International Journal of Agronomy and Plant Production, 4(5), 873-883.

2. Tarla, D. N., Meutchieye, F., Assako, V. A., Fontem, D. A., \& Kome, J. J. A. (2013). Exposure of market gardeners during pesticide application in the western highlands of Cameroon. Sch. J. Agric. Sci, 3(90), 172-177.

3. Kopondo, F. B. O. (2004). Notes on African indigenous vegetables and edible mushrooms for Tertiary Level Institute. Moi University, Nairobi, Kenya.

4. Ngapgue, J. N. (2007). Le maraîchage et le vivrier marchand comme solution à la crise caféière dans la région de Foumbot (Doctoral dissertation, 
Thèse de Doctorat (PhD) de Géographie, Université de Dschang, Cameroun).

5. FAO. (2005). International Code of Conduct on the Distribution and Use of Pesticides Food and Agriculture Organization of the United Nations Rome.

6. Matthews, G. A. (2008). Attitudes and behaviors regarding use of crop protection products- A survey of more than 8500 smallholders in 26 countries. Crop Protection, 27: 834- 846.

7. Nkemleke, E. E., (2016). Use of pesticides in the production of vegetables in M'muockngie. University of Dschang, Department of Geography, Master's dissertation. Unpublished.

8. Nkembi, L., \& Atem, T. (2003). A report of the biological and socio-economic activities conducted by the Lebialem Highland forest Project. Report submitted to the royal society for the production of birds, UK.

9. Tarla, D. N., Tchamba, N. M, Fontem, D. A, Tanga, G., Baleguel, P. N., \& Baleguel, D. P. (2014). Environmental and Socio-economic implications of pesticide applications on green economy of Central African Sub region by 2035. International Journal of Environmental Engineering Science and Technology Research, 2(6):1-9

10. Awazi, N. P., Tchamba, M. N., \& Tabi, F. O. (2019). An assessment of adaptation options enhancing smallholder farmers resilience to climate variability and change: Case of Mbengwi Central Sub-Division, North-West Region of Cameroon. African Journal of Agricultural Research, 14(6), 321-334.

11. Awazi, N. P., \& Tchamba, M. N. (2018). Determinants of small-scale farmers' adaptation decision to climate variability and change in the North-West Region of Cameroon. Afr J Agric Res, 13, 534-543.

12. Tandi, T. E., Wook, C. J., Shendeh, T. T., Eko, E. A., \& Afoh, C. O. (2014). Small-scale tomato cultivators' perception on pesticides usage and practices in Buea Cameroon. Health, 6(21), 29452958.

13. Ajayi, O. O. (2000). Pesticide Use Practices, Productivity and Farmers' Health: The Case of Cotton-Rice Systems in Côte d'Ivoire, West Africa.

14. Rola, A. C., \& Pingali, P. L. (1993). Pesticides, rice productivity, and farmers' health: an economic assessment. IRRI CABI.

15. Antle, J. M, Cole, D. C., \& Crissman C. C. (1998). The Role of Pesticides in Farm Productivity and Farmer Health. In: Crissman, C. C., Antle, J. M., \& Capalbo, S. M., (eds) Economic, Environmental, and Health Trade-offs in Agriculture: Pesticides and Sustainability of Andean Potato Production, Kluwer Academic Publishers, Dordrecht, Boston and London.

16. Kenko, N. D, Asanga, B. F., Ngameni, T. N., \& Mbida, M. (2017). Environmental and Human Health Assessment in Relation to Pesticide Use by Local Farmers and the Cameroon Development Corporation (CDC), Fako Division, South-West Cameroon European Scientific Journal, 13(21):1857-7881.

17. Tetang, T. J., \& Foka, G. (2008). Utilisation des pesticides dans la zone agricole du Moungoévaluation de l'impact sur l'environnement, la santé des populations et solutions envisageables: cas de la localité de Njombé dans l'arrondissement de Njombé-Penja. African Front for the protection of Nature and Man. 2:12-16.

18. Matthews, G., Wiles, T., \& Baleguel, P. (2003). A survey of pesticide application in Cameroon. Crop Protection, 22(5), 707-714.

19. Amuoh, C. N. (2011). A case study of health risk estimate for pesticide-users of fruits and vegetable farmers in Cameroon. Master in Bioscience Engineering, Ghent University, Belgium. 58.

20. Elizabeth, S., \& Zira, D. Y. (2009). Awareness and effectiveness of vegetable technology information packages by vegetable farmers in Adamawa State, Nigeria. African Journal of Agricultural Research, 4(2), 65-70. 